\title{
The trade in freshwater turtles from Bangladesh
}

\author{
Indraneil Das
}

There are at least 25 species of turtles and tortoises in Bangladesh, with freshwater turtles being particularly abundant. Although these turtles form part of the diet for only a minority of people in the country, they are being exported in increasingly large numbers and this trade could now be threatening this valuable resource.

A cruise in a dinghy down one of Bangladesh's many rivers can rarely be a disappointment for a turtle biologist. Freshwater bodies occupy $8000 \mathrm{sq} \mathrm{km}$ of the country's $144,000 \mathrm{sq} \mathrm{km}$ and there are at least 25 species of turtles and tortoises, 10 per cent of the world's total. The fact that these animals are still abundant is probably due to the fact that 90 per cent of people in Bangladesh are followers of Islam, which forbids the eating of turtle meat, considering it to be unclean.

Export of this natural resource, unlike direct consumption, is not prevented by religious belief, and large numbers of Bangladesh's freshwater turtles are involved in foreign trade. Between December 1988 and February 1989 I conducted a survey of many of the districts of Bangladesh, from Sylhet in the extreme north to Cox's Bazar in the south (Figure 1), to study the distribution patterns and exploitation levels of the turtle and tortoise fauna. This report is based on impressions and observations on the trends of export of freshwater turtles from the country.

The increasing trade levels of freshwater turtles have been recorded by Oliver (1979), Khan (1982) and Fugler (1984), among others, all of whom expressed concern for this resource. The Export Promotion Bureau, the government authority that promotes and monitors the country's foreign trade, records two categories of items of turtles that are legally exported: turtle meat, eggs and 'fins'; and live turtles and 'tortoises' (Anon., 1987). An extract of the most recent data is presented in Tables 1 and 2. Oliver (1979) states that this legal trade represents the 'tip of the iceberg', with much larger numbers being smuggled across the border to Indian states where turtle consumption is heavy and the resource dwindling.

Table 1. Export trends for turtle meat, eggs and 'fins', between fiscal years 1977-78 and 1985-86, expressed as Taka (Bangladesh currency)

\begin{tabular}{lc}
\hline $1977-78$ & 46,000 \\
$1978-79^{*}$ & - \\
$1979-80$ & 69,000 \\
$1980-81^{*}$ & - \\
$1981-82$ & 26,000 \\
$1982-83$ & 70,000 \\
$1983-84^{*}$ & - \\
$1984-85^{*}$ & - \\
$1985-86+$ & 148,000 \\
\hline
\end{tabular}

* No figures available.

+ Up to December 1985.

Source: Anon. (1987)

Table 2. Export trends for live turtles, between fiscal years $1974-75$ and 1985-86, expressed as Taka

$\begin{array}{rr}1974-75 & 1000 \\ 1975-76 & 17,000 \\ 1976-77 & 1,187,000 \\ 1977-78 & 5,520,000 \\ 1978-79 & 6,914,000 \\ 1979-80 & 12,948,000 \\ 1980-81 & 16,326,000 \\ 1981-82 & 22,506,000 \\ 1982-83 & 22,884,000 \\ 1983-84 & 24,251,000 \\ 1984-85 & 23,247,000 \\ 1985-86 & 25,369,000\end{array}$

Source: Anon. (1987) 


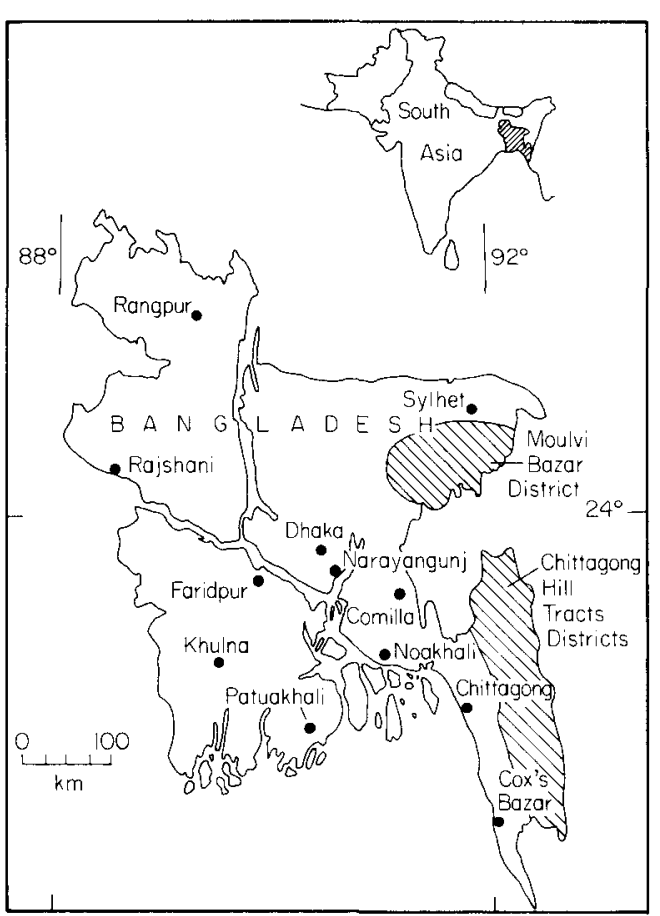

Figure 1. Bangladesh, showing the places mentioned in the text.

At present (1988-1989), 12 business houses are involved in the turtle export trade, all based in the vicinity of the capital city, Dhaka, primarily in the Narayangunj and Mirpur areas. Observations at these holding centres and interviews with exporters made it clear that only softshelled turtles are exported, presumably because these are larger and have a low bone-to-body ratio.

Most surprising, however, is the existing permit system concerning the species that can be legally exported: Trionyx (= Aspideretes) leithii, the peninsular softshell turtle, known only from the rivers and reservoirs of peninsular India; Trionyx cartilagineous (= Amyda cartilaginea), the Burmese softshell turtle, found in South East Asia and not known to occur within, or even approach, the boundaries of Bangladesh; and 'Trionyx certilsfionus', a species that is not recognized in any modern scientific work. Hence, none of the turtle species known to occur in Bangladesh can be exported legally. Observations at the holding centres reveal that two species are exported:
Aspideretes gangeticus, the Indian softshell turtle, found in the river systems of the western parts of Bangladesh; and A. hurum, the peacock softshell turtle, of the eastern and western parts of the country. Locally the first species is known as kocha, and the second as jath, nagashi or bukum. Both are listed in Schedule III of the Bangladesh Wildlife (Preservation) Act of 1974, so should not be captured, killed or traded legally, a fact known by the exporters interviewed.

Collection permits are issued by the Forest Department and turtles are caught by fishermen using hooks and nets, or by hand, from places as far away as Sylhet, Noakhali, Comilla, Faridpur and Patuakhali, and supplied by middlemen to the holding centres near Dhaka. A 'certificate of health' required for export is provided by the government veterinary officers, while the office of the Chief Conservator of Forests issues the 'no objection certificate'. Turtles of $1 \mathrm{~kg}$ or less in weight are not exportable. The government sets the export target for each year by issuing a certain number of permits.

Most consignments are destined for Hong Kong, Singapore, Malaysia, South Korea and Japan. Besides live turtles, other turtle-derived exports have markets in South East Asia. Oil is exported to Japan, Hong Kong and Singapore, and badi, the cartilaginous flaps of softshell turtles that have perished at the holding centres, are sold to Japan and Hong Kong, pre-

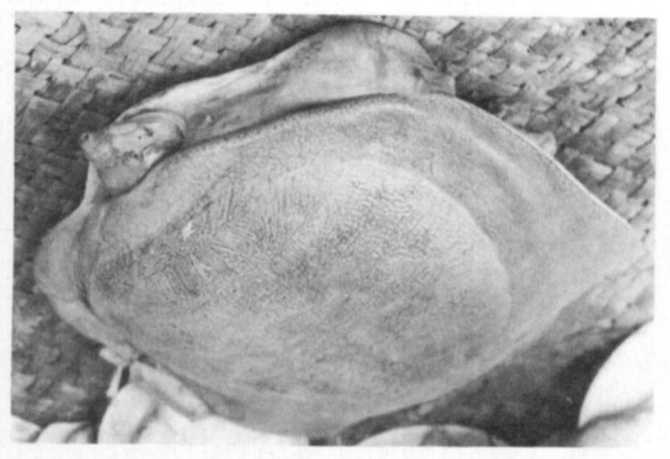

This softshell turtle at a holding centre at Narayangunj, near Dhaka, is one of several thousands that eventually land up in the restaurants and medicine shops of the Far East (Indraneil Das). 
sumably for the manufacture of soups and/or medicines. The bones are used in several countries to make poultry feed and fertilizers.

Turtles caught in places far from Dhaka are transported with the fore and hind limbs stitched together. This practice is believed to account for the mortality that occurs later in transit to markets in the Far East. At least 5 per cent die in the winter months, but a far greater proportion in the summer. At the holding centres, the restraining strings are cut and the animals released in small- to mediumsized ponds, which are surrounded by bamboo fencing. When adequate numbers of turtles are collected they are recaptured, weighed and placed in wicker baskets, without being otherwise restrained, at the rate of 1-7 turtles per basket, depending on the size and weight. The filled baskets are transported to Dhaka International Airport. Supply peaks during the winter months, when consignments leave 6 days a week.

Freshwater turtles are also exported to India but this is undocumented in the official trade statistics. Sundhi, the ubiquitous IndoGangetic flapshell turtle Lissemys punctata, which is inexplicably listed in Appendix I of CITES, forms the mainstay of this trade, with large numbers ending up at Calcutta's Sealdah market.
There appears to be no foreign trade in sea turtles from Bangladesh, although in coastal areas adult sea turtles are sometimes killed for subsistence and eggs are taken. A curio shop at New Elephant Road, Dhaka, displayed a stuffed juvenile green turtle Chelonia mydas, which was offered for Taka $7000(=£ 120)$, and was reportedly from South East Asia (Das, 1989). At St Martin's Island, the southernmost point of Bangladesh, local people sometimes trade sea-turtle meat with the Burmese for rice (G. S. M. Asmat, pers. comm.). Oliver (1979) wrote that the elongated tortoise Indotestudo elongata is collected for export from Bangladesh, a report contradicted by Khan (1982), since the species is not found in large numbers in the country, and exporters did not confirm the report. During the current survey I found a single shell of the species at the West Bhanugach Reserve Forest, Moulvi Bazar district, in a Khasia village, where the animal had recently been eaten. In the districts of Chittagong, Cox's Bazar and the three Hill Tracts districts, both this species and the Asian giant tortoise Manouria emys are reported to occur, where they are caught for food by the tribal Chakmas, the Hindus and the Christians.

Several of the freshwater turtles are not involved in foreign trade, but are exploited

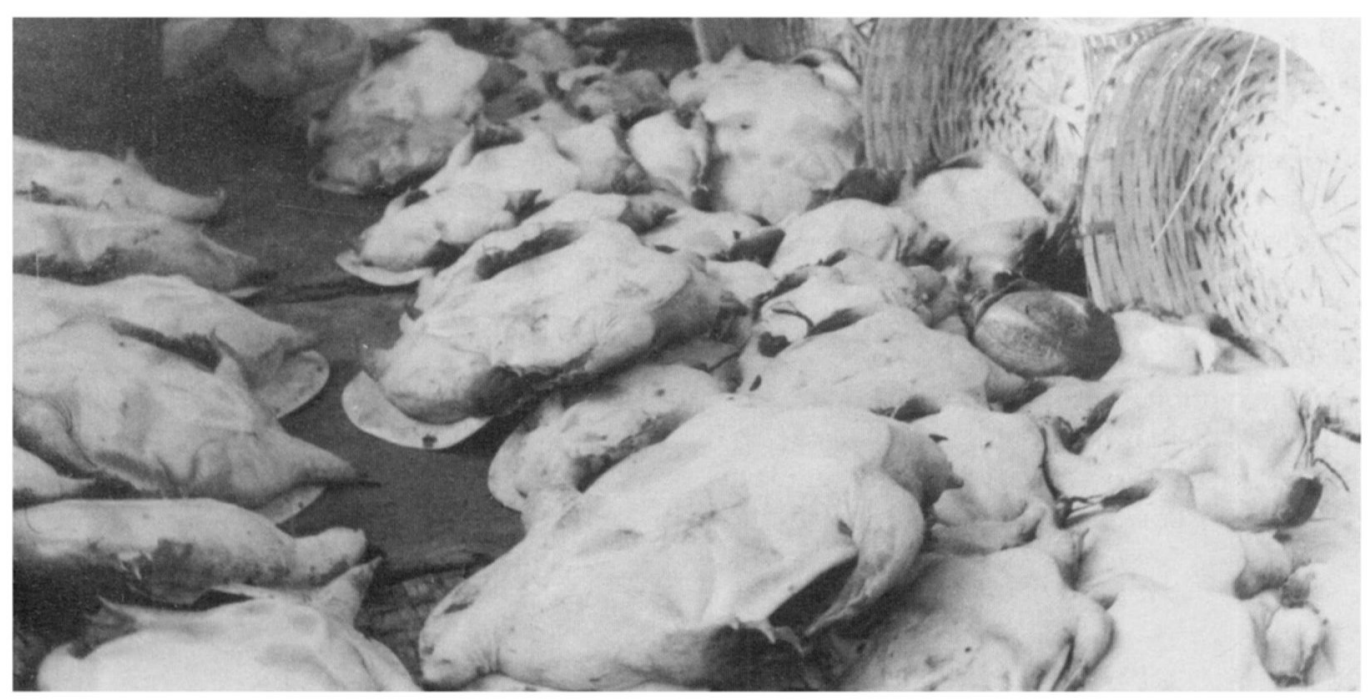

Piled up at the holding centres after arrival from distant landing places, turtles are restrained by stitching the fore and hind limbs together and kept upside down (Indraneil Das). 
internally by the ethnic minorities. These include the narrow-headed softshell turtle Chitra indica, Indian eyed turtle Morenia petersi, river terrapin Batagur baska, brahminy river turtle Hardella thurjii, as well as the larger roofed turtles Kachuga spp. An important market for the freshwater turtles is in the city of Sylhet, where several thousand turtles are sold during the winter months.

The export figures indicate a burgeoning turtle trade from Bangladesh, despite complaints by exporters of diminishing supplies and higher prices asked by the suppliers. More fieldwork is needed to discover whether exploitation levels are sustainable, though some of the areas visited in Sylhet and Dhaka still have good populations of the larger species, while the small, usually non-marketable species, such as the Indian roofed turtle Kachuga tecta, appeared abundant.

More realistic laws, perhaps putting the exploited species in Schedule I of the Wildlife Act, whereby they can be collected in numbers determined after careful surveys, are needed. Better methods of capture, storage and transfer should reduce the mortality rate. A close season could be introduced, allowing no hunting during the nesting season of the softshell turtles. Active efforts need to be made to break the links used in smuggling turtles to the nearby Indian states.

It has been suggested (Fugler, 1984) that export of frozen meat will eliminate loss due to mortality in transit. Research by food technologists is needed in the production of high quality frozen meat, turtle oil, poultry feed and fertilizers, many of which could be used by local industries and individuals. I am convinced that the road to self-sufficiency for Bangladesh will depend partly on how such non-conventional resources are utilized. However, there is much more to be discovered about the ecology of these turtles and the implications of exploitation before we can pro- ceed to use them sustainably.

\section{Acknowledgments}

My work on the freshwater turtles of Bangladesh was funded by the Fauna and Flora Preservation Society. I thank the Bangladesh Forest Department for permitting me to conduct this study and for providing me with the necessary logistical help, in particular Mr Syed Rahman, Conservator of Forests, and $\mathrm{Mr}$ Abdul Wahab Akonda, Senior Research Officer. Mr Sheikh Mohammed Rashid, graduate student, University of Kent, provided contacts in Bangladesh and suggested localities. Mr Ghulam Mustafa, M. Phil. student, Dhaka University; $\mathrm{Mr}$ Abdulla Al-Javed, graduate student, Jahangirnagar University; Mr Monjurul Hannan Khan, Assistant Secretary, Ministry of Agriculture; Mr Anisuzzaman Khan, Secretary, Nature Conservation Movement of Bangladesh; Mr Mohammed Nurul Haque, M.Sc Zoology, Chittagong University; and Mr Abdul Wahab Akonda gave company and useful advice during the fieldwork.

\section{References}

Anon. 1987. Export from Bangladesh during the fiscal years $1972-73$ to $1985-86$. Export Promotion Bureau, Dhaka.

Das, I. 1989. Sea turtles and coastal habitats in south-eastern India. Report to the Sea Turtle Rescue Fund, Center for Marine Conservation, Washington DC.

Fugler, C.M. 1984. The commercially exploited Chelonia of Bangladesh: taxonomy, ecology, reproductive biology and ontogeny. Bangladesh Fish. Inf. Bull. 2, 1-52.

Khan, M.A.R. 1982. Chelonians of Bangladesh and their conservation. J. Bombay. nat Hist. Soc. 79, 110-116.

Oliver, R.C.D. 1979. Wildlife conservation and management in Bangladesh. Report to the FAO, Rome.

Indraneil Das, Madras Crocodile Bank Trust, Vadanemmeli, Perur Post, Mahabalipuram Road, Madras 603 104, India. 